is still more intensive research work that will allow us a more ingenious attack upon the parasite by methods which it may be practicable to use upon an immense scale at reasonable cost.

So much for preventive research. But protection from disease involves also its curative or palliative treatment; and here we come, for the first time, to the work of the medical profession as ordinarily understood, whether that of the physician or of the surgeon. When disease is beginning or has been established, the doctor is concerned to give his help in the most effective way to the single individual before him. This offers him an intricate set of problems which make his work a special branch of applied science in which high arts of skill are based upon the knowledge available. He cannot act effectively until he has found not only the nature of the disorder present but also its particular manifestations in that individual case. The very fact that he must avoid opening the body to look inside it has led to the development of intricate devices for observing and deducing the actual facts from the outside. I need not dwell upon the skill needed by the competent physician, nor upon the manipulative wonders now made possible to the surgeon by Lister's work: nor, again, need I do more than point to the high responsibilities undertaken by the physician or surgeon to whom a human life is entrusted. At every point their knowledge and skill depend upon the results of research work of many kinds, and their powers can only advance as research work progresses.

Lastly, there remains to consider, in the definition I am following, the protection of the body from accident, and its repair. The study of accidents has led to much profitable research work, of which some of the chief has been done under the Industrial Health Research Board. Accidents can be sorted out into those due to the unfitness of particular workers for given tasks, or to states of mind, or to conditions of fatigue and other states of the body, or, again, to the absence of proper protective devices and administrative rules. When their causation is accurately found, preventive work is at once rightly guided.

Under this last head, too, there is the skilled work of the surgeon in repairing physical damage done to the body. But we can only point to this here as completing our rapid survey of the whole campaign in the medical field. It is worthy of note that in coming to the end of this general story, we find ourselves close to the beginning of it again. Surgery has brought us near to the study of heredity again with which we started. For uncounted centuries the surgeon has repaired so far as possible the injuries of man's body in warfare and accident, and his chief concern has always been at least to prevent death by loss of blood. There is no more ancient surgical problem than that of whether a healthy man can lend some of his blood to save the life of another. Nearly three hundred years ago Dr. Lower of Oxford showed to King Charles II. and the early Royal Society that one dog's blood might be transfused into another dog to replace its own. But it has only been in the last twenty years that we have learned why it is that, while the blood of one man given to a patient who has suffered loss by bleeding may be fatal, that of another man may have no ill-effects and may restore life--and happily that knowledge came in time to save many thousands of lives in the War. Careful laboratory studies have shown that every human being belongs to one of four groups, distinguished by the different precipitating powers of their bloods, one against another. These subtle blood differences, far more subtle than any chemical analysis could detect, are of daily importance in surgery. They play a part also now in the study of human inheritance with which we began this survey.

$$
\text { (To be continued.) }
$$

\title{
Oriental Studies in the University of Chicago*
}

I $\mathrm{N}$ the past ten years the United States have made remarkable advances in archæological research in both the New World and the Old. In America itself the whole range of continental civilisation in one form or another from Alaska to Peru has been brought under investigation by university departments and public or semi-public institutions. In particular, the activities of the Carnegie Institution of Washington in Central America and of the Smithsonian Institution in the south-western United States have contributed materially to the advancement of archæological science through the intensive studies by means of which they are gradually filling in details of the chronological sequence in the development of culture in these areas.

In the Old World, both independently and in cooperation with European scientific bodies, American

* The Oriental Institute of the University of Chicago: in Commemoration of the Dedication of the Oriental Institute Building, Dec. 5, 1931. Pp. iv +68 . 25 cents. archæologists have extended their activities over a wide area. The American Schools in France, Athens, and Jerusalem and the expedition of the University of Pennyslvania, in conjunction with the British Museum, at Ur have achieved results of signal importance in the investigation of the history of man and his early civilisation. Less widely known, perhaps, but not of less moment, are the operations of the Oriental Institute of the University of Chicago, of which some account is given in a recent publication issued in commemoration of the opening of new buildings.

When the Oriental Institute was created by the trustees of the University of Chicago and organised by Dr. J. H. Breasted in 1919, its aim was to become " a research laboratory for the investigation of the early human career", and to trace "the course of human development from the merely physical man disclosed by the palæontologist to the rise and advance of civilised societies, the product of social and material evolution culminating in

No. 3275 , VoL. 130] 
social idealism ". It was felt that the proper field for its operations could be only the Near East, the region around the eastern end of the Mediterranean. The formation of the Institute was made possible by the generosity, first of John D. Rockefeller, jr., and then of a number of other benefactors. Field expeditions were sent out and the work of the Institute rapidly outgrew the capacity of its first headquarters in Haskell Hall. In April 1930, ground was broken for a new building, which was completed in April 1931. In this the work of the Institute is now installed and completely equipped for its threefold activities of work in the field, study in the laboratory, and the publication and dissemination of results.

In the field, the Institute now maintains twelve expeditions, engaged in collecting original evidence relating to the origin and development of civilisation. Of these, six are concerned with ancient Egypt, two with Iraq, and four are distributed in Anatolia, Syria, Palestine, and Persia respectively.

In Egypt the work of the six expeditions, though not all are engaged in actual excavation, is so distributed as to cover the development of Egyptian civilisation from the very earliest times to the nineteenth dynasty, or even beyond. The Prehistoric Survey under Dr. Kenneth S. Sandford of Oxford has made a detailed investigation of the Nile valley, finding the earliest evidence of man yet discovered in the Near East at the bottom of the gravels of the former Nile valley, and determining the date of the desiccation of North Africa and the formation of the Sahara. At Sakkara, the expedition under Prof. Prentice Duell has launched a programme for the complete record in five folio volumes of the great treasury of relief paintings in the masonry tombs of the cemetery of ancient Memphis. After nine years' work, Dr. Alan Gardiner and Dr. A. de Buck have completed the copying of the Coffin Texts from Middle Kingdom burials, which are essential for the study of the Book of the Dead. These are now being edited and will be published in a series of five volumes. In association with the Egypt Exploration Society, the Institute is saving the records of the beautiful temple of Seti I. at Abydos, "the loveliest works of art of the ancient world". These will also be published, mostly in colour, under the editorship of Prof. Gardiner, while the work is being carried on by Miss Amice M. Calverley, assisted by Miss Broome. Mrs. N. de G. Davies is also engaged in copying, in colour, paintings in the tombs of the great Theban cemetery. These paintings, together with series previously painted by Mrs. Davies for Dr. Gardiner, are to be published, the first volume appearing in 1932 .

At ancient Thebes the Institute has its largest undertaking in the Near East, in the Epigraphic and Architectural Survey Expedition. The work of this expedition was begun in 1924-25, and with it is now combined the headquarter work of the Institute, for which a new building, in CaliforniaSpanish style, has recently been erected at Luxor. For seven years this expedition has been at work on the colossal temple of Medinet Habu and associated structures under Prof. Uvo Holscher. These excavations have revealed the surprising fact that the largest halls of the palace of Rameses III. had vaulted ceilings and were not flat-roofed as were the temples.

In Western Asia, as in Egypt, the work of the Institute has been planned on lines which are at once comprehensive and at the same time admit of expansion without danger of overlap and waste of effort. Two expeditions are working in the "Highland Zone" under the general direction of Dr. $\mathrm{H}$. Frankfort. Four mounds are included in the concession which the Institute holds from the Government of Iraq. Of these mounds, Tell Asmar (Ashnunnak) is the most important. Here extensive headquarters have been erected. A large palace of Sumerian age has been discovered, of which the excavation is to be completed in the current year; while on another mound at Khafaji, about ten miles away, a large fortified enclosure with temples and dwellings has been uncovered. South of the "Highland Zone", where the cities and palaces of the Assyrians are important sources for evidence of a composite culture which draws its material from both north and south, the Institute is excavating the palace of Sargon II. at Khorsabad. Here Dr. Edward Chiera is following excavations begun by the French more than eighty years ago. Many valuable relief-sculptures have been discovered, including a huge winged bull, partly in the round, which, on the allocation of the Iraq Government, has been brought to Chicago.

In Anatolia, excavations on the Hittite city mound of Alishar in 1930 and 1931 have added this as the third of the sites on which clay tablets of Hittite cuneiform have been found. This expedition has done pioneer work in plotting the archæological levels, with the result that the careful listing and sequence identification of types makes available for the first time a history of the pottery in Hittite territory. A discovery of which the precise significance is as yet difficult to forecast is the apparent survival to-day of ancient Hittite speech in a small isolated village of Anatolia. It has been recorded by Dr.J. Mészáros, of the Angora Museum, and is to be published by the Institute.

In Syria, exploration has identified an ancient mound as the city of Calneh, to which reference is made by the prophets Amos and Isaiah as one of the Assyrians' greatest enemies in the west. A concession for the excavation of this site and a. neighbouring mound has just been granted by the French authorities under their mandate. Headquarters are being erected and work will be begun on the two mounds simultaneously. The Palestinian expedition is occupied in the investigation of the city of Megiddo, one of the most important of strategic points in the history of the country. The Institute has recently acquired control of the whole site, an area of more than thirteen acres, and is now stripping off systematically stratum after stratum of the deposits. Up to the present, the expedition has descended to the stratum of the Hebrew kings. The finds included the stables in which Solomon kept the blooded horses imported from Egypt for 
sale to the Hittites. An interesting innovation in the work on this site is the employment in air photography of a small captive balloon which carries a camera operated from the ground. Its use is fully described for the first time by Mr. P. L. Guy in Antiquity, June 1932.

A concession from the Persian Cabinet to explore and restore the palace of Persepolis has been inoperative until recently owing to lack of funds; but a generous anonymous donation has now made it possible to begin work. Dr. E. Herzfeld, of the University of Berlin, has been placed in charge of the excavation. As a preliminary, and in order to provide accommodation for the expedition, six chambers in the palace have been cleared. These chambers have afforded some interesting material, which inter alia indicates that they had once been part of the quarters of the harem of Darius.

Of the activities of the Institute in research and publication in Chicago, no more can be said here than that they keep fully abreast of the strenuous work of the expeditions in the field in dealing with the original material, and at the same time foster inquiry on other and cognate lines. Throughout its activities the characteristic feature of the work of the Institute is the breadth of vision with which its operations have been planned, combined with a singleness of direction towards the aim which was marked out for the Institute at its inception. It is scarcely necessary to indicate to what an extent in this, as in other matters, the Institute is indebted to its director, Dr. J. H. Breasted.

\section{Obituary}

\section{Santos-Dumont}

$\mathrm{T}$ HE death at São Paulo, Brazil, on July 23, of M. Alberto Santos-Dumont, at the age of fiftynine years, removes another of the few remaining pioneers through whose efforts mechanical flight was achieved. Santos-Dumont was the first in Europe to make a public flight in a heavier-thanair machine, while his numerous experiments with dirigible balloons stimulated the progress of airship construction. His enthusiasm and intrepidity led him into many adventures, and his flights with small airships in the neighbourhood of Paris some thirty years ago made his name famous throughout the world.

Santos-Dumont was born on a large coffee estate at São Paulo on July 20, 1873, and it was during a visit of his family to France in 1892 that he began his work on dirigible balloons. By 1898 he was in possession of his first airship, and during the next few years he constructed about a dozen of various sizes, driven by internal combustion engines. With one of these, on Oct. 19, 1901, he made a flight from St. Cloud around the Eiffel Tower and back, in $29 \frac{1}{2}$ minutes, and thus secured the prize of 125,000 francs offered by $M$. Deutsch de la Meurthe. To commemorate the event, the Brazilian Government struck a special medal. The airship in which the feat was accomplished was of $22,000 \mathrm{cub}$. ft. capacity, and was driven by a 12 h.p. engine. During his experiments Santos-Dumont had many narrow escapes, and on one occasion had to be rescued from the roof of the Trocadero by firemen. His airships were all of the non-rigid type.

From the airship Santos-Dumont next turned to the aeroplane, then engaging the attention of the Voisins, Ferber, Archdeacon, Blériot, and others in France. Though familiar with the gliding experiments of Octave Chanute, little was yet known by workers in Europe of the aeroplane of the Wright brothers and of their historic flights in December 1903 at Kitty Hawk, South Carolina. By the beginning of 1906, however, Santos-Dumont had constructed a biplane with wings of box-kite form, and with this machine, on Aug. 22 that year, made the first public flight on record in the old World.
The same year he made other short flights. The machine was called The Bird of Prey. "Its main double-decker planes ", wrote Miss Gertrude Bacon, "were tilted up at a considerable angle. There was no tail, but in front a big box-kite elevator; so that the thing appeared to fly tail foremost, or as someone said, like a duck with its neck outstretched. On a light, open framework in the midst, mounted on bicycle wheels, was the 50 horse-power Antoinette motor, driving the propeller at the back, and the sort of wicker wastepaper basket in which the aviator stood.'

According to the Times, M. Santos-Dumont will be buried in the family vault at São Paulo, over which a monument will be erected identical with that set up some years ago at St. Cloud to mark his historic flight of 1901 .

\section{Prof. A. Humboldt Sexton}

Prof. A. Humbold Sexton died on June 21, at Jersey, at the age of seventy-eight years, after a long illness. He was the eldest son of Dr. George Sexton, who was well known in his time as a lecturer on spiritualism and later as a Christian apologist, and he was educated at private schools and the Royal School of Mines. He obtained a Royal Exhibition tenable at the Royal College of Science, Ireland, in 1871. In 1873 he became assayer to the Mining Company of Ireland, and in the following year was appointed chemist to the Broughton Copper Works.

Appointed science master to the Wedgwood Institute, Burslem, in 1881, in the following year Sexton became lecturer in chemistry and metallurgy at the Manchester Technical School. Two years later he was appointed professor of metallurgy at the Glasgow and West of Scotland Technical College, a position which he held until his retirement in 1909 with the title of emeritus professor.

Prof. Sexton was a past-president of the West of Scotland Iron and Steel Institute, and his numerous books on chemistry, metallurgy, and refractories were well known and much used in schools and colleges. He also published many papers in technical and scientific publications. 